\title{
Roseateles depolymerans gen. nov., sp. nov., a new bacteriochlorophyll a-containing obligate aerobe belonging to the $\beta$-subclass of the Proteobacteria
}

Tetsushi Suyama, ${ }^{1}$ Toru Shigematsu, ${ }^{1}$ Shinichi Takaichi, ${ }^{2}$
Yoshinobu Nodasaka, ${ }^{3}$ Seizo Fujikawa, ${ }^{4}$ Hiroyuki Hosoya, ${ }^{1}$
Yutaka Tokiwa, ${ }^{1}$ Takahiro Kanagawa ${ }^{1}$ and Satoshi Hanada ${ }^{1}$

Author for correspondence: Tetsushi Suyama. Tel: +81 29854 6591. Fax: +81 298546587 e-mail: sutet@nibh.go.jp
${ }^{1}$ National Institute of Bioscience and Human Technology, 1-1 Higashi, Tsukuba, lbaraki 305-8566, Japan

2 Biological Laboratory, Nippon Medical School, Kawasaki 211-0063, Japan

3,4 School of Dentistry ${ }^{3}$ and Institute of Low Temperature Science ${ }^{4}$, Hokkaido University, Sapporo 060, Japan

\begin{abstract}
Strains 61A' $(T=$ type strain) and 61B2, the first bacteriochlorophyll (BChl) acontaining obligate aerobes to be classified in the $\beta$-subclass of the Proteobacteria, were isolated from river water. The strains were originally isolated as degraders of poly(hexamethylene carbonate) (PHC). The organisms can utilize PHC and some other biodegradable plastics. The strains grow only under aerobic conditions. Good production of $\mathrm{BChl} a$ and carotenoid pigments is achieved on PHC agar plates and an equivalent production is observed under oligotrophic conditions on agar medium. Spectrometric results suggest that $B C h l a$ is present in light-harvesting complex $I$ and the photochemical reaction centre. The main carotenoids are spirilloxanthin and its precursors. Analysis of the 165 rRNA gene sequence indicated that the phylogenetic positions of the two strains are similar to each other and that their closest relatives are the genera Rubrivivax, Ideonella and Leptothrix with similarities of 96.3, 96.2 and $96.1 \%$, respectively. The cells are motile, straight rods and contain poly- $\beta$ hydroxybutyrate granules. Ubiquinone-8 is the predominant quinone. Vitamins are not required for growth. The G+C content of genomic DNA is 66.2-66.3 mol\%. Genetic and phenotypic features suggest that the strains represent a new genus in the $\beta$-subclass which is evenly distant from known genera. Consequently, the name Roseateles depolymerans gen. nov., sp. nov. is proposed for the strains; the type strain of Roseateles depolymerans is strain 61A' ( = DSM 11813').
\end{abstract}

Keywords: aerobic photosynthetic bacteria, bacteriochlorophyll $a, \beta$-subclass, Proteobacteria, Roseateles depolymerans gen. nov., sp. nov.

\section{INTRODUCTION}

There are some species of bacteriochlorophyll (BChl) $a$-containing bacteria that cannot grow photosynthetically under anaerobic conditions even in light of the effective wavelength. These organisms are referred

\footnotetext{
Abbreviations: $\mathrm{BChl}$, bacteriochlorophyll; $\mathrm{FD}-\mathrm{MS}$, field desorption mass spectrometry; LH-I, light-harvesting complex I; PHB, poly- $\beta$-hydroxybutyrate; PHC, poly(hexamethylene carbonate); UQ-8, ubiquinone with 8 isoprene units.

The GenBank/EMBL accession numbers for the 16S rRNA gene sequences of strains $61 A^{\top}$ and $61 B 2$ are $A B 003623$ and $A B 003625$, respectively.
}

to as aerobic photosynthetic bacteria (Harashima et al., 1982; Shiba, 1989; Shimada, 1995). Although the function of their photosynthetic apparatus has not yet been clarified, light-stimulated growth (Harashima et al., 1987; Yurkov \& Gemerden, 1993) and photosynthetic activity (Harashima et al., 1982; Kortlüke et al., 1997; Okamura et al., 1986; Shiba, 1984; Takamiya \& Okamura, 1984) have been reported in some species of aerobic photosynthetic bacteria. Yurkov \& Gemerden (1993) hypothesized an advantage of having both photosynthetic and heterotrophic metabolisms in terms of adaptation to the environment with altering light/dark conditions under aerobic 
conditions. Some physiological changes related to adaptation to light/dark have been reported (Takaichi et al., 1991; Tilden et al., 1997).

Aerobic photosynthetic bacteria have been isolated from various environments: freshwater (Fuerst et al., 1993), marine cyanobacterial mat (Yurkov et al., 1994), cyanobacterial mat from warm/hot spring (Hanada et al., 1997; Yurkov \& Gemerden, 1993; Yurkov \& Gorlenko, 1992, 1993; Yurkov et al., 1993) and surfaces of seaweeds (Shiba, 1991; Shiba \& Simidu, 1982). Currently, aerobic photosynthetic bacteria are classified into the following genera: Erythrobacter and Roseobacter for marine species; and Porphyrobacter, Erythromicrobium and Roseococcus for freshwater species. Recently, two genera, Sandaracinobacter and Erythromonas, were separated from Erythromicrobium (Yurkov et al., 1997). Furthermore, similar isolates have been reported from soil (Saitoh \& Nishimura, 1996), surfaces of plants (Urakami et al., 1993), nodules of legumes (Evans et al., 1990), food, animal feed and sewage sludge (Nishimura et al., 1981), some of which are currently classified into genera which have been considered as typical nonphototrophs: Acidiphilium (possessing zinc-substituted BChl a) (Wakao et al., 1996), Bradyrhizobium (Evans et al., 1990; Young et al., 1991) and Methylobacterium (Green \& Bousfield, 1983; Urakami et al., 1993). So far, all of the genera described above have been phylogenetically classified into the $\alpha$-subclass of the Proteobacteria. Five genera, Erythrobacter, Erythromicrobium, Erythromonas, Porphyrobacter and Sandaracinobacter, belong to the $\alpha-4$ group where aerobic photosynthetic species are predominant and the others belong to the $\alpha-1$ to $\alpha-3$ groups, which contain close relatives of typical anoxygenic photosynthetic bacteria (Hanada et al., 1997; Shimada, 1995; Turova et al., 1995; Young et al., 1991; Yurkov et al., 1994, 1997). No aerobic photosynthetic bacterium has been reported outside of the $\alpha$-Proteobacteria.

Two new obligate aerobes containing $\mathrm{BChl} a$, strain $61 \mathrm{~A}^{\mathrm{T}}$ (= DSM $11813^{\mathrm{T}} ; \mathrm{T}=$ type strain) and strain 61B2 (=DSM 11814), were isolated from river water by screening aliphatic polycarbonate-degrading microorganisms (Suyama et al., 1998). Phylogenetic analysis based on 16S rRNA comparisons revealed that these strains belong to the $\beta$-subclass of the Proteobacteria; the strains are thought to be the first aerobic photosynthetic bacteria found in this taxon.

In the present study, morphological, physiological, biochemical and genetic characteristics of the strains are described and a new genus name, Roseateles depolymerans gen. nov., sp. nov., is proposed for the isolates.

\section{METHODS}

Origin of strains. Strains $61 \mathrm{~A}^{\mathrm{T}}$ and $61 \mathrm{~B} 2$ were isolated from the Hanamuro River in Tsukuba, Ibaraki Prefecture of Japan. The strains were isolated with a medium containing emulsified poly(hexamethylene carbonate) (PHC) as a substrate at $30^{\circ} \mathrm{C}$ (Suyama et al., 1998).

The type strain of Rubrivivax gelatinosus (DSM $1709^{\mathrm{T}}=$ ATCC $17011^{\mathrm{T}}=$ NCIB $8290^{\mathrm{T}}=\mathrm{LMG} 4311^{\mathrm{T}}$ ) used in this study as a reference species was purchased from Deutsche Sammlung von Mikroorganismen und Zellkulturen (DSMZ, Braunschweig, Germany).

Culture media. The following media were used in the present study. The agar plates were prepared by adding $1.5 \%(\mathrm{w} / \mathrm{v})$ Bacto agar (Difco) to the media. PHC medium was used for isolation and maintenance of original culture line. CAV medium was used for the other physiological tests.

The PHC medium contained $\left(\mathrm{1}^{-1}\right)$ : $1 \mathrm{~g}$ PHC (emulsified, number-average molecular mass $\overline{\mathrm{Mn}}=2000$; Toagosei) $; 1 \mathrm{~g}$ $\left(\mathrm{NH}_{4}\right)_{2} \mathrm{SO}_{4} ; 0 \cdot 1$ g yeast extract (Difco) $; 20 \mathrm{mg} \mathrm{CaCl} .2 \mathrm{H}_{2} \mathrm{O}$; $10 \mathrm{mg} \mathrm{NaCl} ; 10 \mathrm{mg} \mathrm{FeSO}{ }_{4} .7 \mathrm{H}_{2} \mathrm{O} ; 0.5 \mathrm{mg} \mathrm{Na}{ }_{2} \mathrm{MoO}_{4} .2 \mathrm{H}_{2} \mathrm{O}$; $0.5 \mathrm{mg} \mathrm{Na} \mathrm{WO}_{4} .2 \mathrm{H}_{2} \mathrm{O} ; 0.5 \mathrm{mg} \mathrm{MnSO}_{4} ; 60 \mathrm{mg}$ surfactant (Plysurf A210G; Daiichi Kogyo Seiyaku); 0.2 $\mathrm{g} \mathrm{KH}_{2} \mathrm{PO}_{4}$; and $1.6 \mathrm{~g} \mathrm{~K}_{2} \mathrm{HPO}_{4}(\mathrm{pH} \mathrm{7.0})$.

The CAV medium contained $\left(1^{-1}\right): 2 \mathrm{~g}$ Casamino acids

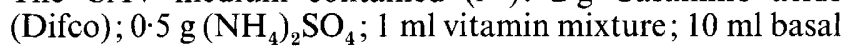
salt solution; and $25 \mathrm{ml} 200 \mathrm{mM}$ potassium phosphate buffer $(\mathrm{pH} 7 \cdot 0)$. The composition of the basal salt solution and the vitamin mixture were previously described (Hanada et al., 1997).

Physiological tests and determination of growth conditions. The ability of the strains to grow photosynthetically under anaerobic conditions was investigated both on the agar plates and in liquid culture in the light. The anaerobic or semi-aerobic growth on agar plates was assessed in an anaerobic jar with Anaero Pack or Campylo Pack (Mitsubishi Gas Chemical), respectively. The photoheterotrophic growth was ascertained using PE medium (Hanada et al., 1995b), which contains acetate, glutamate and succinate as electron donors. The photoautotrophic growth in the presence of reduced sulfur compounds was determined in a

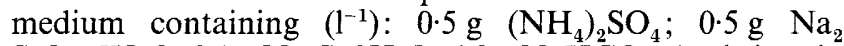
$\mathrm{S}_{2} \mathrm{O}_{3} .5 \mathrm{H}_{2} \mathrm{O} ; 0 \cdot 1 \mathrm{~g} \mathrm{Na}_{2} \mathrm{~S} .9 \mathrm{H}_{2} \mathrm{O} ; 4 \cdot 2 \mathrm{~g} \mathrm{NaHCO}_{3} ; 1 \mathrm{ml}$ vitamin mixture; $5 \mathrm{ml}$ basal salt solution (Hanada et al., 1997); and a final concentration of $10 \mathrm{mM}$ potassium phosphate buffer (pH 7.0).

The growth rates as a function of temperature were determined in CAV medium. The vitamin requirement was determined at $30^{\circ} \mathrm{C}$ with special CAV medium lacking the vitamin mixture and containing vitamin-free Casamino acids (Difco). The final reading was obtained after nine serial transfers. The growth rates at various $\mathrm{pH}$ were also determined at $30^{\circ} \mathrm{C}$ in a series of $\mathrm{CAV}$ media that were buffered by $10 \mathrm{mM}$ sodium citrate (pH 3-6), $10 \mathrm{mM}$ potassium phosphate ( $\mathrm{pH} 7--8)$ or $10 \mathrm{mM}$ sodium/glycine buffer (pH 9-11).

For the analysis of photosynthetic pigments, colonies formed on PHC agar plate medium incubated for $3 \mathrm{~d}$ were used. Pigments were extracted from cells with acetone/ methanol $(7: 2, \mathrm{v} / \mathrm{v})$. The crude extract was analysed with an HPLC system equipped with a $\mu$ Bondapak C18 column $(8 \times 100 \mathrm{~mm}$; Waters) eluting with methanol (Takaichi \& Shimada, 1992). Major carotenoids were purified from silica gel TLC (Merck) developed with n-hexane and acetone $(4: 1$, $\mathrm{v} / \mathrm{v})$. Absorption spectra were recorded with a photodiode array detector (200-800 nm, MCPD-3600; Otsuka Electronics) attached to the HPLC apparatus (Takaichi \& Shimada, 1992). The molar absorption coefficients in methanol $\left(90.6 \mathrm{mM}^{-1} \mathrm{~cm}^{-1}\right.$ at absorption maxima for carotenoids 
and $54.9 \mathrm{mM}^{-1} \mathrm{~cm}^{-1}$ at $770 \mathrm{~nm}$ for BChl a) were used for quantification. The molecular masses were determined by field desorption mass spectrometry (FD-MS), using a double-focusing GC-MS equipped with field desorption apparatus (M-2500; Hitachi) (Takaichi, 1993).

Quinones were extracted with chloroform/methanol (2:1, $\mathrm{v} / \mathrm{v}$ ) from cells grown for $1 \mathrm{~d}$ in CAV medium. The extract was purified by the method of Hiraishi et al. (1996) and analysed by HPLC using a Gold HPLC System (Beckman) with a ZORBAX-ODS column (Shimadzu).

The organic substrate utilization activities were determined with BiOLOG GN and GP Microplates (Biolog) according to the recommended protocol of the manufacturer. Gelatinase activity was determined by the standard method (Smibert \& Krieg, 1981). Utilization of hydrogen gas was investigated with $15 \%(\mathrm{v} / \mathrm{v})$ hydrogen in air using carbonfree medium at $30^{\circ} \mathrm{C}$.

Nitrogen-fixing ability was tested by acetylene reduction assay (Inoue et al., 1996). Overnight culture was prepared in a medium that contained $\left(1^{-1}\right): 5$ g glucose; $1 \mathrm{~g}$ Agar Noble (Difco); $10 \mathrm{ml}$ basal salt solution; and $25 \mathrm{ml} 200 \mathrm{mM}$ potassium phosphate buffer ( $\mathrm{pH} 7 \cdot 0)$. The culture was placed in a rubber-capped tube with $15 \%(\mathrm{v} / \mathrm{v})$ acetylene and incubated at $30^{\circ} \mathrm{C}$. Reduction of acetylene was assayed with a GC-8A gas chromatograph (Shimadzu) with a Unibeads C 60/80 column (GL Science).

Electron microscopy. Negatively stained cells and ultrathin sections of the cells were observed with a model H-7000 electron microscope operating at $75 \mathrm{kV}$ (Hitachi). The cells were collected from PHC agar plates (3d) or from CAV liquid medium $(1 \mathrm{~d})$. Cells on a collodion membrane were negatively stained with $1 \%(\mathrm{w} / \mathrm{v})$ aqueous uranyl acetate. Ultrathin sections were prepared by a previously described method (Hanada et al., 1995a). The cells were suspended in Kellenberger buffer (Kellenberger et al., 1958) and embedded in $1 \%(\mathrm{w} / \mathrm{v})$ agar. The specimen was fixed with $2.5 \%$ $(\mathrm{w} / \mathrm{v})$ glutaraldehyde and $1 \%(\mathrm{w} / \mathrm{v}) \mathrm{OsO}_{4}$, prestained with ruthenium red and uranyl acetate, and embedded in epoxy resin.

DNA composition and phylogenetic analysis. Genomic DNA was extracted and purified by the method of Marmur (1961). Almost full-length 16S rRNA genes were amplified by PCR with a pair of primers designed from positions 8-27 and 1492-1511 of the Escherichia coli 16S rRNA gene (Brosius et al., 1978; Weisburg et al., 1991). The PCR products cloned into plasmid vector ( $\mathrm{pT} 7 \mathrm{Blue} \mathrm{T}$-Vector; Novagen) were sequenced separately by an automated sequencer (ABI model 373A; Applied Biosystems) from both forward- and reverse-strands using twelve kinds of primers. The detailed procedure for the sequencing was described previously (Suyama et al., 1998).

The $\mathrm{G}+\mathrm{C}$ content was determined by the protocol of Kamagata \& Mikami (1991).

Nucleotide sequence accession numbers. Accession numbers for the reference 16S rRNA gene sequences were as follows: Alcaligenes latus, D88007; Brachymonas denitrificans, D14320; Comamonas testosteroni, M11224; Ideonella dechloratans, X72724; Leptothrix cholodnii, X97070; Leptothrix discophora, L33974; Leptothrix mobilis, X97071; Polaromonas vacuolata, U14585; Rhodocyclus tenuis, D16208; Rhodoferax fermentans, D16212; Rubrivivax gelatinosus, D16213; Sphaerotilus natans, Z18534; Thiobacillus thermosulfatus, U27839; and Variovorax paradoxus, D30793.

\section{RESULTS}

\section{Strains and growth conditions}

Two strains, $61 \mathrm{~A}^{\mathrm{T}}$ (soft and smooth colony) and 61B2 (harder and larger colony than that of $61 \mathrm{~A}^{\mathrm{T}}$ ), were isolated from the Hanamuro River (Ibaraki Prefecture, Japan) as two PHC-degrading strains; the strains cometabolically utilized PHC (Suyama et al., 1998). Both of the strains formed pink colonies on PHC agar plates within 2-3 d, making clear zones caused by degradation of PHC around their colonies. Other biodegradable plastics, poly ( $\varepsilon$-caprolactone) and poly(tetramethylene carbonate) (Suyama \& Tokiwa, 1997), were degraded in the same way.

The strains were able to grow in CAV medium buffered at pH 5-8 (Fig. 1a). Growth was observed at 5-43 ${ }^{\circ} \mathrm{C}$, and an incubation temperature of $45^{\circ} \mathrm{C}$ was lethal (Fig. 1b). Optimal pH and temperature for the growth of these strains were $\mathrm{pH} 6.5$ and $35^{\circ} \mathrm{C}$, respectively. No vitamins were required for growth; subculturing strains $61 \mathrm{~A}^{\mathrm{T}}$ and $61 \mathrm{~B} 2$ in CAV medium lacking vitamins had no effect on growth.

Both of the strains produced a musty odour and mucus. Strain 61B2 tended to make white floc in liquid culture whereas strain $61 \mathrm{~A}^{\mathrm{T}}$ did not.
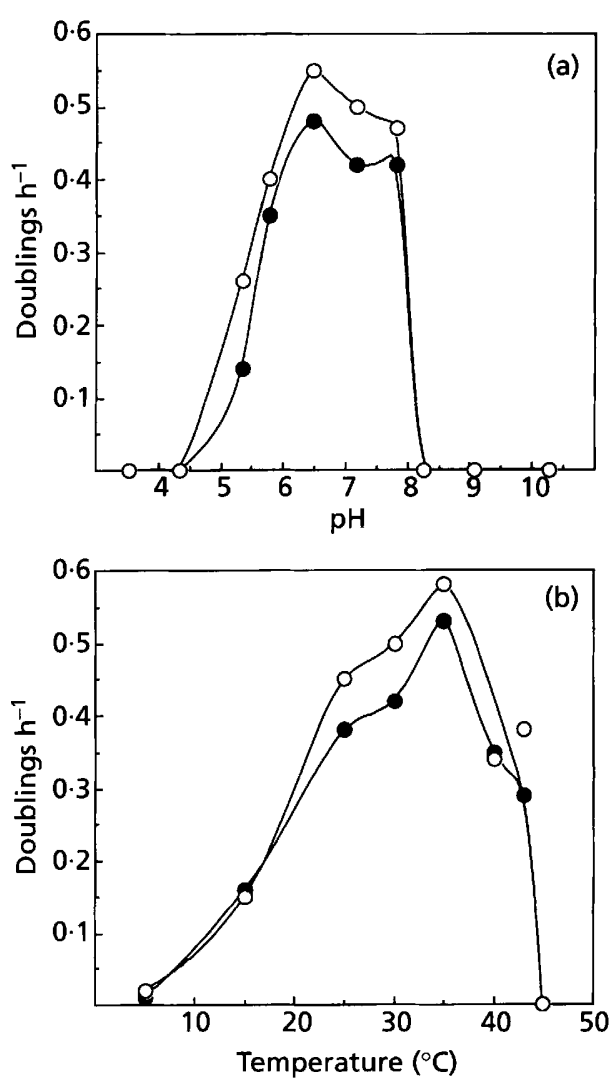

Fig. 1. Growth rate of strains $61 \mathrm{~A}^{\top}(0)$ and $61 \mathrm{~B} 2(\mathrm{O})$ as a function of $\mathrm{pH}$ at $30^{\circ} \mathrm{C}(\mathrm{a})$ and as a function of temperature at $\mathrm{pH} 7.0$ (b). Cells were grown in CAV medium under aerobic conditions in the dark. 

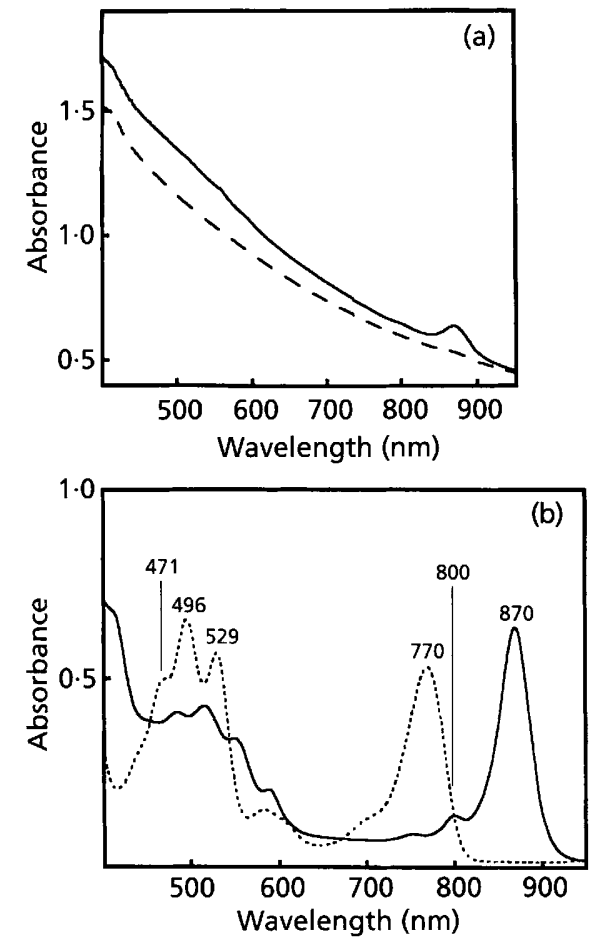

Fig. 2. Absorption spectra of (a) intact cells of strain $61 A^{\top}$ grown on PHC agar plates (solid line) and CAV agar plates (dashed line) for $5 \mathrm{~d}$; and (b) ultrasonically disrupted membrane in potassium phosphate buffer, $\mathrm{pH} 6.8$ (solid line), and acetone/methanol $(7: 2, \mathrm{v} / \mathrm{v})$ extract (dotted line) of the cells grown on $\mathrm{PHC}$ agar plates. Spectra were recorded with a Beckman DU-640 spectrophotometer.

\section{Photosynthetic pigments}

The strains grew on agar plates of CAV, nutrient broth or $0.1 \%$ skim milk media, but the colonies were colourless. When the strains were grown on agar plates with a lower concentration of carbon sources (e.g. in the presence of $0.02 \%$ Casamino acids), weak pigmentation was observed. In vivo absorption spectra of intact cells of strain $61 \mathrm{~A}^{\mathrm{T}}$ (pigmented and nonpigmented) are shown in Fig. 2(a).The cells grown on PHC agar plates showed a large absorption peak at $870 \mathrm{~nm}$, whereas those grown on CAV agar plates showed no significant peak around this wavelength. No pigmentation was observed in liquid-cultured cells.

The strains did not grow anaerobically and photosynthetically under conditions used for purple sulfur or non-sulfur bacteria. Growth and the production of pigments by the strains were blocked under anaerobic conditions. The strains were able to grow and produced the pigments in semi-aerobic conditions $\left(6-10 \%, \mathrm{v} / \mathrm{v}, \mathrm{O}_{2}\right)$.

At present, the PHC agar plate is the best medium for pigment production by strains $61 \mathrm{~A}^{\mathrm{T}}$ and $61 \mathrm{~B} 2$. Greater pigment production was observed in dark-grown cells compared to light-grown cells. Ultrasonically disrupted cells had absorption maxima at 482, 515, 550, 590,800 and $870 \mathrm{~nm}$ (solid line; Fig. 2b). The
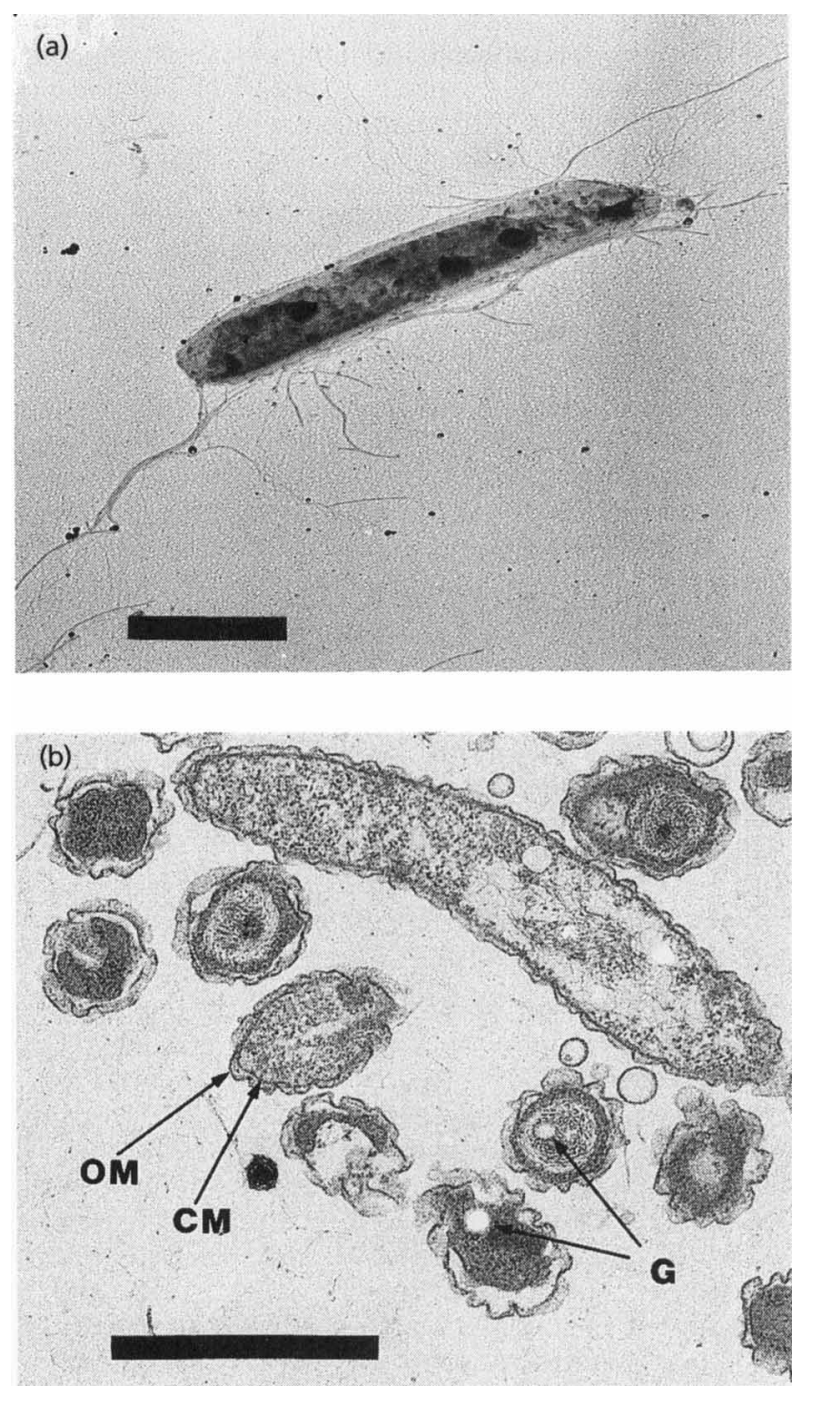

Fig. 3. Electron micrographs of negatively stained cells of strain $61 \mathrm{~A}^{\top}$ grown in CAV medium for $1 \mathrm{~d}$ (a) and ultrathin crosssections of cells of strain $61 A^{\top}$ grown on a PHC agar plate for $3 \mathrm{~d}(\mathrm{~b})$. The outer membrane (OM), cytoplasmic membrane (CM) and intracellular granules (G) are shown in (b). Cells were poststained with uranyl acetate and lead citrate. No invaginations of intracytoplasmic membranes were observed. Bar, $1 \mu \mathrm{m}$.

absorption peaks of the pigments extracted with acetone/methanol $(7: 2, \mathrm{v} / \mathrm{v})$ were shifted as indicated in the figure (dotted line; Fig. 2b). BChl $a$ with phytol ester was confirmed by the retention time on HPLC and absorption spectrum. Analysis of carotenoids using HPLC and FD-MS revealed that the major carotenoid of these strains was spirilloxanthin $\left(M_{\mathrm{r}}\right.$ $596 ; 89$ and $88 \mathrm{~mol} \%$ of total carotenoids in strains $61 \mathrm{~A}^{\mathrm{T}}$ and $61 \mathrm{~B} 2$, respectively). The precursors of spirilloxanthin, i.e. $\mathrm{OH}$-spirilloxanthin $(2$ and $3 \mathrm{~mol} \%$, respectively), anhydrorhodovibrin (8 and $7 \mathrm{~mol} \%$ ) and 3,4-dehydrorhodopin ( 1 and $2 \mathrm{~mol} \%$ ), were also detected as minor components. The molar ratios of total carotenoids/BChl $a$ were 0.65 (strain $61 \mathrm{~A}^{\mathrm{T}}$ ) and 0.58 (strain 61B2). Spheroidene (or sphero- 
idenone), which is one of the major carotenoids of Rubrivivax gelatinosus, the phylogenetic neighbour described below, was not detected.

The production of photosynthetic pigments in Rubrivivax gelatinosus cells was determined under the same conditions as the two strains using CAV or PHC medium. Rubrivivax gelatinosus produced $\mathrm{BChl} a$ and carotenoids in liquid CAV medium or on CAV agar plates. However, pigment production was not observed on PHC agar plates.

\section{Morphology and ultrastructure}

Strains $61 \mathrm{~A}^{\mathrm{T}}$ and $61 \mathrm{~B} 2$ had similar morphological characteristics. Cells of strain $61 \mathrm{~A}^{\mathrm{T}}$ grown in CAV medium were motile (motility was observed only in the early exponential phase in a liquid culture), Gramnegative rods that were $0.5 \times 2 \mu \mathrm{m}$ with flagella (Fig. $3 a)$. No intracytoplasmic membranes were observed in ultrathin sections of pigmented cells of strain $61 \mathrm{~A}^{\mathrm{T}}$ (Fig. 3b). Intracellular granules were observed, some of which were considered to be identical to the poly- $\beta$ hydroxybutyrate (PHB) granules determined by Nile Blue A staining (Suyama et al., 1998). No remarkable differences were observed in ultrathin sections between the cells with and without photosynthetic pigments.

\section{Phylogenetic analysis}

The obtained sequence of the 16S rRNA genes of each isolate consisted of $1452 \mathrm{bp}$. The sequences of strains $61 \mathrm{~A}^{\mathrm{T}}$ and $61 \mathrm{~B} 2$ were identical except for a single base (i.e. guanine at $E$. coli position 648 in strain $61 \mathrm{~A}^{\mathrm{T}}$ was replaced by adenine in strain $61 \mathrm{~B} 2$ ).

Fig. 4 shows the phylogenetic positions of the strains among representative members of the $\beta$-subclass of the Proteobacteria, determined by the neighbour-joining method (Saitou \& Nei, 1987). The sequence of Rhodocyclus tenuis was used as the outgroup reference. Alcaligenes latus, Ideonella dechloratans, Rubrivivax gelatinosus, Sphaerotilus natans and the Leptothrix species were the phylogenetic neighbours of strains $61 \mathrm{~A}^{\mathrm{T}}$ and $61 \mathrm{~B} 2$. Rubrivivax gelatinosus was the only phototrophic species among closely related organisms. The closest relatives of the two strains were Rubrivivax gelatinosus, Ideonella dechloratans, Leptothrix cholodnii and Leptothrix discophora with similarities of 96.3, $96 \cdot 2,96 \cdot 1$ and $96 \cdot 1 \%$, respectively.

\section{Physiological and other properties}

The results of the nutritional and biochemical tests carried out on strains $61 \mathrm{~A}^{\mathrm{T}}$ and $61 \mathrm{~B} 2$ are summarized in Table 1. The reference data for the phylogenetic neighbours are listed together. The strains could utilize the organic acids and carbohydrates listed in Table 1 as sole carbon sources. The strains utilized organic acids (e.g. L-malate, succinate, etc.) and the reducing monohexoses (e.g. glucose, fructose, etc.) well. Some other physiological traits of the two strains were reported previously (Suyama et al., 1998). The major quinone

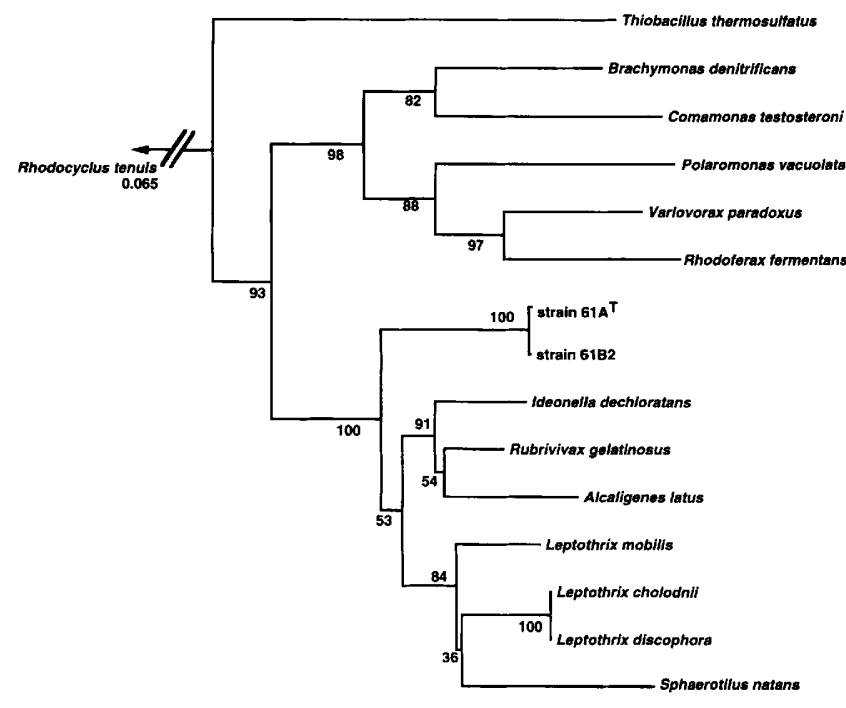

$\underline{0.01}$

Fig. 4. Phylogenetic positions of strains $61 \mathrm{~A}^{\top}$ and $61 \mathrm{~B} 2$ among neighbouring species selected from the $\beta$-subclass of the Proteobacteria. Bar, 1 nucleotide substitution per 100 nucleotides in 165 rRNA gene sequences. The numbers at the nodes of the tree indicate bootstrap values (\%) for each node of 1000 bootstrap resamplings.

component of strains $61 \mathrm{~A}^{\mathrm{T}}$ and $61 \mathrm{~B} 2$ was UQ-8 (ubiquinone with 8 isoprene units). The $\mathrm{G}+\mathrm{C}$ contents of the strains, determined by HPLC, were $66 \cdot 3$ (strain $61 \mathrm{~A}^{\mathrm{T}}$ ) and $66 \cdot 2$ (strain $61 \mathrm{~B} 2$ ) $\mathrm{mol} \%$.

\section{DISCUSSION}

Strains $61 \mathrm{~A}^{\mathrm{T}}$ and $61 \mathrm{~B} 2$ were characterized previously as physiologically new strains that co-metabolically utilized aliphatic polycarbonates (Suyama et al., 1998). The two strains grew only under aerobic conditions with production of $\mathrm{BChl} a$. Light did not support growth of the strains under anaerobic conditions. These features are similar to those of aerobic photosynthetic bacteria belonging to the $\alpha$-subclass of the Proteobacteria (Evans et al., 1990; Fuerst et al., 1993; Green \& Bousfield, 1983; Shiba, 1991; Shiba \& Simidu, 1982; Urakami et al., 1993; Wakao et al., 1996; Young et al., 1991; Yurkov et al., 1993, 1997; Yurkov \& Gorlenko, 1992). The absence of intracytoplasmic membranes as shown in Fig. 3(b) has also been reported in some other aerobic photosynthetic bacteria (Hanada et al., 1997; Yurkov et al., 1994). The 16S rRNA gene sequences indicate that the strains are distinguishable from the $\alpha$-subclass of the Proteobacteria and that they belong to the $\beta$-subclass. The predominant presence of UQ-8 in the isolates as the major quinone component supports their taxonomic position in the $\beta$-subclass of the Proteobacteria (Hiraishi et al., 1996).

Absorption maxima at 870 and $800 \mathrm{~nm}$ in Fig. 2(b) indicate the presence of $\mathrm{BChl} a$ in the light-harvesting complex I (LH-I) and the photochemical reaction 
Table 1. Characteristics of the species phylogenetically close to strains $61 \mathrm{~A}^{\top}$ and $61 \mathrm{~B} 2$

,$+ \geqslant 90 \%$ positive;,$- \leqslant 10 \%$ positive; $\mathrm{d}, 11-89 \%$ of the strains positive; NT, not tested. The following references were used: Imhoff \& Trüper (1989); Kersters \& De Ley (1984); Malmqvist et al. (1994); Suyama et al. (1998); and Willems et al. (1991).

1 , Strains $61 \mathrm{~A}^{\mathrm{T}}$ and $61 \mathrm{~B} 2 ; 2$, Ideonella dechloratans; 3, Rubrivivax gelatinosus; 4, Alcaligenes latus; 5, Leptothrix discophora; and 6, Sphaerotilus natans.

\begin{tabular}{|c|c|c|c|c|c|c|}
\hline Characteristic & 1 & 2 & 3 & 4 & 5 & 6 \\
\hline Motility & + & + & + & + & + & + \\
\hline Flagellation & Several, polar & Several, polar & 1, polar & 5-10, peritrichous & 1, polar & Polar bunch \\
\hline Cytochrome $c$ oxidase & + & + & NT & + & NT & + \\
\hline Catalase & - & + & NT & $\mathrm{NT}$ & NT & + \\
\hline Formation of sheaths & - & - & - & - & + & + \\
\hline Phototrophic growth & - & - & + & - & - & - \\
\hline Autotrophic growth with hydrogen & - & NT & + & + & - & NT \\
\hline Nitrogen fixation & - & NT & + & + & NT & NT \\
\hline Nitrate reduction & - & $+($ or chlorate $)$ & NT & - & NT & NT \\
\hline Gelatinase & + & NT & + & + & $\mathrm{NT}$ & + \\
\hline Accumulation of PHB & + & NT & NT & + & + & + \\
\hline \multicolumn{7}{|l|}{ Pigments: } \\
\hline BChl $a$ & $+^{*}$ & - & $+\uparrow$ & - & - & - \\
\hline Carotenoids & Spirilloxanthin* & - & $\begin{array}{l}\text { Spheroidene, } \\
\text { OH-spheroidene, } \\
\text { spirilloxanthin } \dagger\end{array}$ & - & - & - \\
\hline Growth factors required & - & $+\ddagger$ & Biotin, thiamin & NT & Vitamin $\mathbf{B}_{12}$ & Vitamin $\mathrm{B}_{12}$ \\
\hline \multicolumn{7}{|l|}{ Carbon sources utilized: } \\
\hline Acetate & $\mathrm{d}$ & + & + & - & - & + \\
\hline Pyruvate & + & + & + & - & + & + \\
\hline Lactate & + & + & + & + & - & + \\
\hline L-Malate & + & NT & + & + & + & + \\
\hline Succinate & + & + & + & + & + & + \\
\hline Citrate & + & NT & + & $\mathrm{d}$ & - & + \\
\hline D-Ribose & - & NT & NT & - & - & NT \\
\hline D-Glucose & + & + & + & + & + (cannot grow) & + \\
\hline D-Fructose & + & + & + & + & - & + \\
\hline D-Galactose & + & NT & NT & - & $\mathrm{NT}$ & + \\
\hline Sucrose & - & NT & NT & + & $+($ not all strains $)$ & + \\
\hline Glycerol & - & $\mathrm{NT}$ & - & + & + & + \\
\hline Mannitol & + & NT & - & - & NT & + \\
\hline Sorbitol & - & NT & - & - & NT & + \\
\hline Isolation source & Water & Water & Mud & Soil & Water & Water \\
\hline $\mathrm{G}+\mathrm{C}$ content $(\mathrm{mol} \%)$ & $66 \cdot 2-66 \cdot 3$ & $68 \cdot 1$ & $70 \cdot 0-72 \cdot 5$ & $69 \cdot 1-71 \cdot 1$ & $67.8-71 \cdot 1$ & $69 \cdot 9$ \\
\hline
\end{tabular}

* The pigments are produced by cells grown aerobically on PHC agar medium in the dark.

$\uparrow$ The pigments are produced by cells grown anaerobically in the light.

$\ddagger$ See reference by Malmqvist et al. (1994).

centre. In the pigmented cells, the molar ratio of carotenoids/BChl $a$ in the strains was always about $0 \cdot 6$. This stoichiometry is quite similar to the LH-I in Rhodospirillum rubrum (Cogdell et al., 1982), and a major proportion of the carotenoids is considered to be bound to the complex. Although most of the species of aerobic photosynthetic bacteria are known to contain carotenoids which do not bind to the photosynthetic apparatus (e.g. erythroxanthin sulfate), such components were not detected in strains $61 \mathrm{~A}^{\mathrm{T}}$ and 61B2.

The species listed in Table 1 are the phylogenetic neighbours of the strains suggested by analysis based on the 16S rRNA gene sequences (Fig. 4). The presence of motility, flagellation, PHB granules, oxidase and gelatinase are common characteristics of the species in this taxon. The absence of sheaths clearly distinguishes the strains from the genera Sphaerotilus and Leptothrix. The difference in the utilization pattern of carbon sources (Table 1) suggests that the strains are distinct from known species. The $\mathrm{G}+\mathrm{C}$ contents of the two strains are comparatively low in the phylogenetic cluster and distinguish the strains from relatives in this taxon. The formation of photosynthetic pigments is the most remarkable characteristic of strains $61 \mathrm{~A}^{\mathrm{T}}$ and 61B2. Although Rubrivivax gelatinosus is the only species containing BChl $a$ among the phylogenetic neighbours, the growth physiology and the production of pigments in Rubrivivax gelatinosus were different from those of the two strains. Rubrivivax gelatinosus is a typical anoxygenic phototrophic bacteria and grows under both aerobic and anaerobic conditions. Rubrivivax gelatinosus has the spheroidene and spirilloxanthin series as major carotenoid species while the two strains have only the spirilloxanthin series. Nitrogen fixation and autotrophic growth on hydrogen were reported for Rubrivivax gelatinosus (Imhoff \& Trüper, 1989), but were not found in the two strains. Rubrivivax gelatinosus requires biotin and thiamin for growth, whereas the strains could grow in a vitaminfree medium.

The 16S rRNA gene sequence similarities to the 
phylogenetic neighbours, Rubrivivax gelatinosus, Ideonella dechloratans and the Leptothrix species, were $96.3,96.2$ and $96.1 \%$, respectively. The distances to each of the genera are sufficient to consider creation of a new genus. The bootstrap probabilities indicated in Fig. 4 show that the genera around strains $61 \mathrm{~A}^{\mathrm{T}}$ and 61B2 are equally dispersed under the branch with a reliability of $100 \%$. Genetic and phenotypic features suggest that strains $61 \mathrm{~A}^{\mathrm{T}}$ and $61 \mathrm{~B} 2$ represent a new genus in the $\beta$-subclass of the Proteobacteria which is evenly distant from known genera. The name Roseateles depolymerans gen. nov., sp. nov. is therefore proposed for the strains.

\section{Description of Roseateles gen. nov.}

Roseateles (ro.se.a.te'les. L. adj. roseus rose-coloured, pink; Gr. adj. ateles defective, incomplete; N.L. masc. $\mathrm{n}$. roseateles the rose-coloured incomplete photosynthetic bacterium).

Cells are motile, Gram-negative straight rods. Cells possess PHB granules as a storage material and reproduce by binary fission. The bacterium grows heterotrophically under aerobic conditions. BChl $a$ with phytol ester and carotenoid pigments are formed. Colonies are pink in colour under conditions suitable for photosynthetic pigment production. The bacterium cannot grow anaerobically even in the light. The major quinone is UQ-8. On the basis of the results of a $16 \mathrm{~S}$ rRNA gene sequence comparison, the bacteria belong to the $\beta$-subclass of the Proteobacteria. DNA G+C content is $66 \cdot 2-66 \cdot 3 \mathrm{~mol} \%$. The type species is Roseateles depolymerans.

\section{Description of Roseateles depolymerans sp. nov.}

Roseateles depolymerans (de.po.ly'me.rans. N.L. v. depolymerare depolymerize; N.L. part. adj. depolymerans depolymerizing).

Characteristics are the same as those given in the description of the genus. Lives in river water. BChl $a$ with phytol ester and spirilloxanthin are present along with the LH-I when cells are grown aerobically on agar plates supplemented with low levels of carbon sources, e.g. $0 \cdot 02 \%$ Casamino acids. Grows well heterotrophically with rich media containing $0.2 \%$ Casamino acids, $0.8 \%$ nutrient broth or $0.1 \%$ skim milk, under aerobic conditions. In this case, BChl $a$ and carotenoids are hardly produced. Hydrogen is not utilized for autotrophic growth. Positive for gelatinase and oxidase. Negative for catalase, nitrogen fixation, nitrogen reduction and denitrification. No vitamins are required for growth. Optimum $\mathrm{pH}$ for the growth is $\mathrm{pH} 6.5$ and optimum temperature is $35^{\circ} \mathrm{C}$. The culture is not maintained at $45^{\circ} \mathrm{C}$. The bacterium can grow on D-glucose, D-fructose, D-galactose, mannitol, pyruvate, lactate, L-malate, succinate, citrate, Casamino acids or yeast extract as a sole carbon source. Degrades PHC, poly(tetramethylene carbonate) and poly( $\varepsilon$ - caprolactone) by means of co-metabolism. Type strain is $61 \mathrm{~A}^{\mathrm{T}}$, which has been deposited in the Deutsche Sammlung von Mikroorganismen und Zellkulturen as DSM $11813^{\mathrm{T}}$.

\section{ACKNOWLEDGEMENTS}

We wish to thank Hans G. Trüper (Universität Bonn) for advice and correction of the Latin names.

\section{REFERENCES}

Brosius, J., Palmer, J. L., Kennedy, J. P. \& Noller, H. F. (1978). Complete nucleotide sequence of a 16S ribosomal RNA gene from Escherichia coli. Proc Natl Acad Sci USA 75, 4801-4805.

Cogdell, R. J., Lindsay, J. G., Valentine, J. \& Durant, I. (1982). A further characterisation of the B890 light-harvesting pigmentprotein complex from Rhodospirillum rubrum strain S1. FEBS Lett 150, 151-154.

Evans, W. R., Fleischman, D. E., Calvert, H. E., Pyati, P. V., Alter, G. M. \& Rao, N. S. S. (1990). Bacteriochlorophyll and photosynthetic reaction center in Rhizobium strain BTAi 1. Appl Environ Microbiol 56, 3445-3449.

Fuerst, J. A., Hawkins, J. A., Holmes, A., Sly, L. l., Moore, C. J. \& Stackebrandt, E. (1993). Porphyrobacter neustonensis gen. nov., sp. nov., an aerobic bacteriochlorophyll-synthesizing budding bacterium from fresh water. Int $J$ Syst Bacteriol 43, 125-134.

Green, P. N. \& Bousfield, I. J. (1983). Emendation of Methylobacterium Patt, Cole, and Hanson 1976; Methylobacterium rhodium (Heumann 1962) comb. nov. corrig.; Methylobacterium radiotolerans (Ito and lizuka 1971) comb. nov. corrig.; and Methylobacterium mesophilicum (Austin and Goodfellow 1979) comb. nov. Int J Syst Bacteriol 33, 875-877.

Hanada, S., Hiraishi, A., Shimada, K. \& Matsuura, K. (1995a). Chloroflexus aggregans sp. nov., a filamentous phototrophic bacterium which forms dense cell aggregates by active gliding movement. Int J Syst Bacteriol 45, 676-681.

Hanada, S., Hiraishi, A., Shimada, K. \& Matsuura, K. (1995b). Isolation of Chloroflexus sp. and related thermophilic photosynthetic bacteria from hot springs using an improved isolation procedure. J Gen Appl Microbiol 41, 199-130.

Hanada, S., Kawase, Y., Hiraishi, A., Takaichi, S., Matsuura, K., Shimada, K. \& Nagashima, K. V.P. (1997). Porphyrobacter tepidarius sp. nov., a moderately thermophilic aerobic photosynthetic bacterium isolated from a hot spring. Int $J$ Syst Bacteriol 47, 408-413.

Harashima, K., Nakagawa, M. \& Murata, N. (1982). Photochemical activity of bacteriochlorophyll in aerobically grown cells of heterotrophs Erythrobacter species (OCh 114) and Erythrobacter longus (OCh 101). Plant Cell Physiol 23, 185-193.

Harashima, K., Kawazoe, K., Yoshida, I. \& Kamata, H. (1987). Light-stimulated aerobic growth of Erythrobacter species OCh 114. Plant Cell Physiol 28, 365-374.

Hiraishi, A., Ueda, Y., Ishihara, J. \& Mori, T. (1996). Comparative lipoquinone analysis of influent sewage and activated sludge by high-performance liquid chromatography and photodiode array detection. J Gen Appl Microbiol 42, 457-469.

Imhoff, J. F. \& Trüper, H. G. (1989). Genus Rhodocyclus Pfennig $1978,285^{\mathrm{AL}}$. In Bergey's Manual of Systematic Bacteriology, vol. 3, pp. 1678-1682. Edited by J. T. Staley, M. P. Bryant, N. Pfennig \& J. G. Holt. Baltimore: Williams \& Wilkins.

Inoue, A., Shigematsu, T., Hidaka, M., Masaki, H. \& Uozumi, T. 
(1996). Cloning, sequencing and transcriptional regulation of the draT and draG genes of Azospirillum lipoferum FS. Gene 170, 101-106.

Kamagata, Y. \& Mikami, E. (1991). Isolation and characterization of a novel thermophilic Methanosaeta strain. Int J Syst Bacteriol 41, 191-196.

Kellenberger, E., Ryter, A. \& Sechand, J. (1958). Electron microscopic study of DNA-containing plasms. II. Vegetative and mature phage DNA as compared with normal bacterial nucleoids in different physiological states. $J$ Biophys Biochem Cytol 4, 671-678.

Kersters, K. \& De Ley, J. (1984). Genus Alcaligenes Castellani and Chalmers 1919, 936 ${ }^{\mathrm{AL}}$. In Bergey's Manual of Systematic Bacteriology, vol. 1, pp. 361-373. Edited by N. R. Krieg \& J. G. Holt. Baltimore: Williams \& Wilkins.

Kortlüke, C., Breese, K., Gad'on, N., Labahn, A. \& Drews, G. (1997). Structure of the puf operon of the obligately aerobic, bacteriochlorophyll $a$-containing bacterium Roseobacter denitrificans OCh1 14 and its expression in a Rhodobacter capsulatus puf puc deletion mutant. J Bacteriol 179, 5247-5258.

Malmqvist, Å., Welander, T., Moore, E., Ternström, A., Molin, G. \& Stenström, I.-M. (1994). Ideonella dechloratans gen. nov., sp. nov., a new bacterium capable of growing anaerobically with chlorate as an electron acceptor. Syst Appl Microbiol 17, 58-64.

Marmur, J. (1961). A procedure for the isolation of deoxyribonucleic acid from microorganisms. $J$ Mol Biol 3, 208-218.

Nishimura, Y., Shimadzu, M. \& lizuka, H. (1981). Bacteriochlorophyll formation in radiation-resistant Pseudomonas radiora. $J$ Gen Appl Microbiol 27, 427-430.

Okamura, K., Mitsumori, F., Ito, O., Takamiya, K. \& Nishimura, M. (1986). Photophosphorylation and oxidative phosphorylation in intact cell and chromatophores of an aerobic photosynthetic bacterium, Erythrobacter sp. strain OCh 114. J Bacteriol 168, $1142-1146$.

Saitoh, S. \& Nishimura, Y. (1996). Taxonomic characterization of novel aerobic bacteriochlorophyll-containing bacteria isolated from soil. J Gen Appl Microbiol 42, 121-140.

Saitou, N. \& Nei, M. (1987). The neighbor-joining method: a new method for reconstructing phylogenetic trees. Mol Biol Evol 4, $406-425$

Shiba, T. (1984). Utilization of light energy by the strictly aerobic bacterium Erythrobacter sp. OCh 114. J Gen Appl Microbiol 30, 239-244.

Shiba, T. (1989). Overview of the aerobic photosynthetic bacteria. In Aerobic Photosynthetic Bacteria, pp. 1-8. Edited by K. Harashima, T. Shiba \& N. Murata. Berlin: Springer.

Shiba, T. (1991). Roseobacter litoralis gen. nov., sp. nov., and Roseobacter denitrificans sp. nov., aerobic pink-pigmented bacteria which contain bacteriochlorophyll a. Syst Appl Microbiol 14, 140-145.

Shiba, T. \& Simidu, U. (1982). Erythrobacter longus gen. nov., sp. nov., an aerobic bacterium which contains bacteriochlorophyll a. Int J Syst Bacteriol 32, 211-217.

Shimada, K. (1995). Aerobic anoxygenic phototrophs. In Anoxygenic Photosynthetic Bacteria, pp. 105-122. Edited by R. E. Blankenship, M. T. Madigan \& C. E. Bauer. Dordrecht: Kluwer.

Smibert, R. M. \& Krieg, N. R. (1981). General characterization. In Manual of Methods for General Bacteriology, pp. 409-443. Edited by P. Gerhardt, R. G. E. Murray, R. N. Costilow, E. W. Nester, W. A. Wood, N. R. Krieg \& G. B. Phillips. Washington, DC: American Society for Microbiology.
Suyama, T. \& Tokiwa, Y. (1997). Enzymatic degradation of an aliphatic polycarbonate, poly(tetramethylene carbonate). Enzyme Microb Technol 20, 122-126.

Suyama, T., Hosoya, H. \& Tokiwa, Y. (1998). Bacterial isolates degrading aliphatic polycarbonates. FEMS Microbiol Lett 161, 255-261.

Takaichi, S. (1993). Usefulness of field desorption mass spectrometry in determining molecular masses of carotenoids, natural carotenoid derivatives and their chemical derivatives. Org Mass Spectrom 28, 785-788.

Takaichi, S. \& Shimada, K. (1992). Characterization of carotenoids in photosynthetic bacteria. Methods Enzymol 213, 374-385.

Takaichi, S., Furihata, K. \& Harashima, K. (1991). Light-induced changes of carotenoid pigments in anaerobic cells of the aerobic photosynthetic bacterium, Roseobacter denitrificans (Erythrobacter species OCh 114): reduction of spheroidenone to 3,4dihydrospheroidenone. Arch Microbiol 155, 473-476.

Takamiya, K. \& Okamura, K. (1984). Photochemical activities and photosynthetic ATP formation in membrane preparation from a facultative methylotroph, Protaminobacter ruber strain NR-1. Arch Microbiol 140, 21-26.

Tilden, A. R., Becker, M. A., Amma, L. L., Arciniega, J. \& McGaw, A. K. (1997). Melatonin production in an aerobic photosynthetic bacterium: an evolutionarily early association with darkness. $J$ Pineal Res 22, 102-106.

Turova, T. P., Burkal'tseva, M. V., Bulygina, E. S. \& Gorlenko, V. M. (1995). Phylogenetic position of freshwater erythrobacteria studied by $5 \mathrm{~S}$ rRNA analysis. Microbiology (English translation of Mikrobiologiya) 64, 662-666.

Urakami, T., Araki, H., Suzuki, K. \& Komagata, K. (1993). Further studies of the genus Methylobacterium and description of Methylobacterium aminovorans sp. nov. Int $J$ Syst Bacteriol 43, 504-513.

Wakao, N., Yokoi, N., Isoyama, N. \& 8 other authors (1996). Discovery of natural photosynthesis using Zn-containing bacteriochlorophyll in an aerobic bacterium Acidiphilium rubrum. Plant Cell Physiol 37, 889-893.

Weisburg, W. G., Burns, S. M., Pelletier, D. A. \& Lane, D. J. (1991). $16 \mathrm{~S}$ ribosomal DNA amplification for phylogenetic study. $J$ Bacteriol 173, 697-703.

Willems, A., De Ley, J., Gillis, M. \& Kersters, K. (1991). Comamonadaceae, a new family encompassing the acidovorans rRNA complex, including Variovorax paradoxus gen. nov., comb. nov., for Alcaligenes paradoxus (Davis 1969). Int J Syst Bacteriol 41, 445-450.

Young, J. P. W., Downer, H. L. \& Eardly, B. D. (1991). Phylogeny of the phototrophic rhizobium strain BTAi 1 by chain reactionbased sequencing of a $16 \mathrm{~S}$ rRNA gene segment. $J$ Bacteriol 173, 2271-2277.

Yurkov, V. V. \& Gemerden, H. V. (1993). Impact of light/dark regimen on growth rate, biomass formation and bacteriochlorophyll synthesis in Erythromicrobium hydrolyticum. Arch Microbiol 159, 84-89.

Yurkov, V. V. \& Gorlenko, V. M. (1992). A new genus of freshwater aerobic bacteriochlorophyll $a$-containing bacteria, Roseococcus gen. nov. Microbiology (English translation of Mikrobiologiya) 60, 628-632.

Yurkov, V. V. \& Gorlenko, V. M. (1993). New species of aerobic bacteria from the genus Erythromicrobium containing bacteriochlorophyll a. Microbiology (English translation of Mikrobiologiya) 61, 163-168. 
Yurkov, V. V., Gorlenko, V. M. \& Kompantseva, E. I. (1993). A new type of freshwater orange-colored bacterium Erythromicrobium gen. nov., containing bacteriochlorophyll a. Microbiology (English translation of Mikrobiologiya) 61, 256-260.

Yurkov, V., Stackebrandt, E., Holmes, A. \& 7 other authors (1994). Phylogenetic positions of novel aerobic, bacteriochlorophyll $a$ containing bacteria and description of Roseococcus thiosulfatophilus gen. nov., sp. nov., Erythromicrobium ramosum gen. nov., sp. nov., and Erythrobacter litoralis sp. nov. Int $J$ Syst Bacteriol 44, 427-434.

Yurkov, V., Stackebrandt, E., Buss, O., Vermeglio, A., Gorlenko, V. \& Beatty, J. T. (1997). Reorganization of the genus Erythromicrobium: description of 'Erythromicrobium sibiricum' as Sandaracinobacter sibiricus gen. nov., sp. nov., and of 'Erythromicrobium ursincola' as Erythromonas ursincola gen. nov., sp. nov. Int J Syst Bacteriol 47, 1172-1178. 